Dunamis: Jurnal Teologi dan Pendidikan Kristiani

Volume 5, Nomor 1 (Oktober 2020)

ISSN 2541-3937 (print), 2541-3945 (online)

http://www.sttintheos.ac.id/e-journal/index.php/dunamis

DOI: $10.30648 /$ dun.v5i1.343

Submitted: 23 April 2020

Accepted: 14 Mei 2020

Published: 11 Oktober 2020

\title{
Folklore Saka Mese Nusa sebagai Basis Teologi Lokal dalam Relasi Komunitas Kristen dan Non-Kristen di Seram Bagian Barat
}

\author{
Marcho David Pentury \\ Magister Sosiologi Agama Universitas Kristen Satya Wacana \\ marchojensen@gmail.com
}

\begin{abstract}
This article aimed to read local theological folklore for a society. Folklore is arranged to reconcile differences, especially religion, in a pluralistic society. The method used in this study is a qualitative method by conducting empirical research on the appreciation of folklore saka mene nusa of the West Seram community. The result was that when folklore is appreciated and used as material for local theology, it will result in a moral transformation that reaches nonChristian communities. That means theology does not only build relationships with God, but also solidarity with others.
\end{abstract}

Keywords: public theology; local wisdom; peace; plurality

\begin{abstract}
Abstrak
Tujuan penulisan artikel ini adalah untuk mengusulkan folklore sebagai teologi lokal bagi suatu masyarakat. Folklore diyakini dapat mendamaikan perbedaan, khususnya agama, dalam masyarakat yang majemuk. Metode yang digunakan dalam penelitian ini adalah metode kualitatif dengan melakukan penelitian empiris terhadap penghayatan folklore saka mene nusa masyarakat Seram Bagian Barat. Hasilnya adalah ketika folklore tersebut dihargai dan dijadikan bahan baku teologi lokal, maka hal itu akan menghasilkan transformasi moral yang menjangkau juga komunitas di non-Kristen. Itu artinya teologi tidak hanya membangun relasi kepada Tuhan, namun juga solider dengan sesama.
\end{abstract}

Kata Kunci: teologi publik; kearifan lokal; perdamaian; keberagaman 


\section{PENDAHULUAN}

Teologi bukan hanya, sebatas di teks kitab suci, tetapi jika mengacu pada pendekatan teologi lokal, maka teologi bisa ditemukan di dalam budaya. ${ }^{1}$ Sebab itu, teologi jauh lebih efektif, jika mengakomodasi nilai-nilai budaya. ${ }^{2}$ Dalam kehidupan, manusia selalu terikat dengan konteks (sosial, budaya, suku, sejarah, politik). Konteks yang begitu kompleks dan lokal, terjadi ruang perjumpaan, antara manusia dan Tuhan. Konteks tersebut, harus dimasukkan sebagai unsur untuk berteologi, selain kitab suci dan tradisi teologi, yang bersifat klasik. ${ }^{3}$ Sehingga dalam konteks lokal, Lattu mengusulkan untuk memakai teksteks budaya, seperti Pela-Gandong, sebagai bahan berteologi. Dari cerita ini, kemudian melahirkan teologi yang berbasis pada solidaritas dan persaudaraan, dengan orangorang yang berbeda agama. ${ }^{4}$ Senada dengan hal tersebut, Dawa menjelaskan perlunya teologi yang mempertimbangkan aspek multikultural. Dari hal tersebut, orang bisa

\footnotetext{
${ }^{1}$ Clemens Sedmark, Doing Local Theology (New York: Orbis Books, 2002), 12.

2 Robert J. Schreiter, Rancang Bangun Teologi Lokal, trans. Stephen Suleeman (Jakarta: BPK Gunung Mulia, 2001), 50.

${ }^{3}$ Choan-Seng Song, Sebutkanlah Nama-Nama Kami (Jakarta: BPK Gunung Mulia, 1989), 87.

${ }^{4}$ Izak Lattu, "Kekristenan Poliponik: Mendialogkan Teologi Dan Budaya Lokal," Jurnal Teologi Interdisipliner 4, no. 1 (2009), 98.

5 Markus Dominggus L. Dawa, "Menjadi Jemaat Multikultural: Suatu Visi Untuk Gereja-Gereja
}

menerima mereka yang berbeda seperti etnis Tianghoa. ${ }^{5}$ Dengan demikian, teologi lokal, merupakan suatu respon, terhadap kesadaran bahwa teologi tidak bisa dilepas dari interaksi sosial-budaya, gunanya untuk menjawab, menanggapi tantangan lokalkontekstual.

Teologi lokal dalam tulisan ini adalah teologi yang bercorak induktif, yang dimulai dari hidup sehari-hari, yang berbasis pada folklore saka mese nusa. Folklore saka mese nusa, berasal Seram, yang mewakili dua suku asli (Wemale dan Alune). Secara etimologi kata saka (suku wemale) berarti jaga, mese (suku alune) berarti bae-bae, nusa berarti pulau dan manusia yang mendiaminya. ${ }^{6}$ Saka Mese Nusa, berarti jaga pulau baik-baik. Kondisi menjaga pulau, diartikan sebagai kemampuan mereka mengatasi mental yang penuh dengan hasrat, individualitis, serta tidak bertanggung jawab. Mereka, pada fase ini, mampu melakukan refleksi-formatif dan transformasi, dengan membangun kehi-

Tionghoa Injili Indonesia Yang Hidup Di Tengah Konflik Etnis Dan Diskriminasi Rasial," Veritas: Jurnal Teologi dan Pelayanan 7, no. 1 (2006), accessed October 9, 2020, http://repository.seabs. ac.id/handle/123456789/132.

${ }^{6}$ Wawancara dengan mantan ketua koordinator rajaraja negeri Seram Bagian Barat (ketua Latupatti), Elly Kwalomine (69 Tahun), Piru, 1 juli 2018, pukul 16.00 WITA. 
dupan baru, yang berbasis pada sistem nilai dan norma, yang ada di cerita rakyat saka mese nusa.

Dalam folklore saka mese nusa terkandung sistem kekerabatan dan interaksi, yang menjadi basis kohesi. Basis kohesi ini lahir ketika mereka melewati fase panjang kehidupan di masa lalu, dan pada akhirnya mereka mengangkat komitmen moral kolektif, untuk menguburkan semua paham dan praktik yang menghancurkan dan merusak kehidupan mereka, baik dengan sesama maupun dengan orang yang berbeda agama. Mereka menemukan betapa pentingnya menjaga keamanaan yang paling mendasar (ontological security) bagi tatanan kehidupan untuk saat sekarang maupun masa yang akan datang. Mereka mengusung cerita rakyat saka mese nusa sebagi etik moral. Artinya kehidupan yang bisa hidup berdampingan dengan yang lain.

Bertolak dari hal tersebut, maka penulis mengkonsepkan saka mese nusa sebagai basis teologi lokal dalam relasi Kristen dan non-Kristen di Seram Bagian Barat. Pertimbangannya, karena konflik sektarian antara Kristen dan non-Kristen (Islam) tahun 1999-2004, telah berdampak pada perubahan komposisi komunitas antar umat beragama, dan hal tersebut juga memengaruhi pandangan mereka mengenai interaksi keberagaman di Seram Bagian Barat. Namun ditengah arus perubahan tersebut, komunitas beragama di Seram Bagian Barat, tidak sepenuhnya menanggalkan basis pemahaman tradisionalnya, baik berupa budayawi maupun agamawi. Sebaliknya sejarah panjang pemahaman tersebut, telah membentuk habitus agama, yang dialektis dalam mangadopsi dan menghadaptasi unsur-unsur serta pandangan dunia kebudayaan lokal.

Hal inilah yang menjadi fokus penulisan teologi lokal di dalam artikel ini. Sebab itu penulis memakai folklore saka mese nusa, sebagai struktur kultur yang mendesak masyarakat untuk kembali pada identitas utama, yang dibangun dengan materi-materi tradisional, dalam rangka menjaga dunia komunal, dan dampaknya masyarakat Seram Bagian Barat ada dalam suatu hubungan relasional, yang tidak berusaha untuk saling menguasai. Sedangkan teologi lokal mengacu pada penghargaan yang besar terhadap budaya mempunyai dasar ilahi. ${ }^{7}$ Ini berarti teologi harus membuka hati, untuk mendengarkan budaya. Nilai beserta makna yang ada di dalam budaya bisa dikomunikasikan, untuk menghasilkan makna teologi, yang sesuai dengan

\footnotetext{
${ }^{7}$ Schreiter, Rancang Bangun Teologi Lokal, 54-55.
} 
konteks, termasuk konteks yang multualistik.

Sebab itu, teologi lokal bukan hanya berhenti pada teks kitab suci, tetapi bisa mencari makna terhadap dokumen-dokumen teologi yang tidak dicantumkan dalam teks Kitab Suci. Dokumen teologi tersebut bisa didapatkan dalam cerita rakyat tanpa mengurangi esensi kekristenan yang asasi. Dalam istilahnya Eben Nuban Timo, teologi sudah harus berbunyi polifonik (banyak bunyi), tidak lagi monofonik (satu suara saja). Teologi sudah harus mangakomodir budaya lokal, di mana Kekristenan itu hadir. ${ }^{8}$

Inilah yang menurut penulis harus menjadi substansi refleksi teologi lokal, yang persoalan, bukan hanya meletakan budaya dalam kemasan saja, atau dalam pengertian hanya menghargai budaya saja, melainkan sebagai substansi refleksi teologi, yang muncul dari dalam, sebagai akibat dari pergumulan akan konteks.

\section{METODE PENELITIAN}

Metode penelitian yang digunakan adalah metode kualitatif. Teknik pengumpulan data dilakukan dengan wawancara terbuka dengan informan sehingga nara-

8 Eben N. Timo, Polifonik Bukan Monofonik (Salatiga: Satya Wacana Press, 2015), 338.

9 J. R. Raco, Metode Penelitian Kualitatif, Jenis, Karakteristik, Dan Keunggulannya (Jakarta: Widya Sari Indonesia, 2010), 10. sumber dapat selebar-lebarnya mengungkapkan pikiran serta argumentasi tanpa dibatasi oleh penulis. Langkah berikutnya, penulis menyaring informasi tersebut, agar sesuai dengan kebutuhan penulisan. ${ }^{9}$ Demi efisiensi waktu, maka penulis mengambil salah satu tempat penelitian yang memiliki berbagai keragaman sumber data yang sesuai dengan kebutuhan penulis. ${ }^{10}$ Dengan demikian, penulis mengambil Piru sebagai tempat penelitian (basis research), dengan pertimbangan bahwa negeri Piru merupakan ibu kota kabupaten Seram Bagian Barat, dan juga ada arus mobilisasi orang dari luar negeri Piru dalam rangka untuk mencari pekerjaan, membuka usaha dan lain-lain.

Hasil penelitian tersebut selanjutnya disajikan secara deskriptif-analistis. Langkahnya, konteks kebudayaan diuraikan, kemudian dikaji dengan mengunakan teori folklore dan teologi lokal yang terdapat dimensi relasi lintas komunitas beragama. Selanjutnya mendeskripsikan basis kebudayaan, sebagai tempat perjumpaan antaragama. Setelah melakukan upaya deskripsi dan analisis, Langkah yang terakhir adalah upaya untuk menemukan

10 John W. Creswell, Penelitian Kualitatif Dan Design Riset (Yogyakarta: Pustaka Pelajar, 2015), 205. 
model teologi lokal serta memakai landasan bibilika yang sesuai dengan konteks orang Seram Bagian Barat.

\section{HASIL DAN PEMBAHASAN}

\section{Dari Folklore Menuju Teologi Lokal yang Inklusif}

Aspek budaya tradisional atau folklore, dan teologi lokal menjadi dua bahasan utama dalam memahami karya Ilahi yang melintasi batas-batas agama. Aspek folklore menekankan tentang pertemuan setiap hari dalam relasi informal, yang melalui tradisi lisan, akhirnya ada penciptaan ruang bersama dengan orang yang non-Kristen. Sedangkan teologi lokal berangkat dari kesadaran bahwa teologi tidak bisa dipisahkan dari interaksi budaya, malah sebaliknya iman atau teologi terjadi dalam situasi manusia dengan latar budaya, sosial, dan politiknya.

Paradigma folklore dari Alan Dundes membantu menjelaskan tentang pengetahuan kolektif, yang ada di dalam suatu masyarakat. Folklore terjadi karena ada proses perjumpaan di masa lalu, dan diregenarasikan melintasi ruang dan waktu, melalui tradisi lisan. Perspektif folklore sangat menekankan bahwa setiap kelompok

\footnotetext{
${ }^{11}$ Izak Lattu, "Orality Ritual in Collective Memory: A Theoritical Discussion," Jurnal Pemikiran Sosiologi 6, no. 2 (2019): 94-111.
}

orang terdiri dari satu faktor umum. Faktor itu menjadi dasar untuk menghubungkan mereka, dan di dalamnya memiliki beberapa tradisi yang disebut dengan cara mereka sendiri. ${ }^{11}$ Sebab itu folklore, bukan hanya sebatas pengetahuan masyarakat kolektif, tetapi juga sebagai cerita rakyat, yang memiliki beberapa bentuk seperti tata krama, adat istiadat, ketaatan, legenda, balada, peribahasa, dari masa lalu, dan diregenerasikan melalui tradisi lisan (oral tradition), yang sifatnya bukan statis, tetapi mengalami rekonseptualisasi. ${ }^{12}$

Dikatakan rekonseptualisasi, karena ada ruang perjumpaan dari beberapa entitas berbeda, yang akhirnya menciptakan nilainilai kebaikan, kohesi, dan memperlebar wilayah kultural masyarakat tradisional. Penekanan pada aspek ini menolong penulis untuk memahami folklore, bukan sebagai ruang kultural yang berdinding statik, tetapi check points yang menjadi titik-titik ikatan dalam proses dialog lintas kelompok agama. Hal ini berarti dalam konteks dan waktu tertentu folklore terutunisasi atau terinsitusionalisasi dalam relasi lintas komunitas Kristen dan non-Kristen.

Gagasan dasar teologi lokal dibingkai dari perspektif Robert Schreiter, 
yang menjelaskan bahwa untuk melahirkan epistimologi teologi lokal, maka hal yang harus diperhatikan adalah melihat aspek yang telah menyatu dengan masyarakat, dan hal tersebut bisa didapatkan dalam basis budaya. Teologi perlu mendengarkan nilainilai utama dari budaya, arah, dan juga lambangnya. ${ }^{13}$ Ini merupakan model teologi sungsang dari bawah ke atas, yang melihat gagasan dari aras bawah dan multitude, dapat menjadi kekuatan pendorong untuk menghadapi masalah ketidakadilan sosial di semua bidang dan tingkatan. ${ }^{14}$ Proses ini dilihat sebagai kehadiran Allah dalam sejarah manusia untuk mengatur dan mengontrol seluruh ciptaannya termasuk yang ada di dalam dunia. ${ }^{15}$

Sebab itu dalam merancang bangunan teologi lokal ada dua cara yaitu membuka kultur (opening the culture), dan membuka tradisi gereja (opening the tradition). Aktifitas membuka kultur berkaitan dengan melihat konteks lokal serta mengkaji dan menganalisisnya. ${ }^{16}$ Untuk itu,

\footnotetext{
${ }^{13}$ Schreiter, Rancang Bangun Teologi Lokal, 6.

14 Johanes Baptista Giyana Banawiratma, "Teologi Lokal Dalam Konteks Global," GEMA TEOLOGIKA 1, no. 1 (April 28, 2016): 55, accessed October 9, 2020, http://journal-theo.ukdw.ac.id/ index.php/gemateologika/article/view/211.

${ }^{15}$ Ezra Tari, "Teologi Tongkonan: Berteologi Dalam Konteks Budaya Toraja," EPIGRAPHE: Jurnal Teologi dan Pelayanan Kristiani 2, no. 2 (January 23, 2019): 93, accessed October 9, 2020, http://www.stttorsina.ac.id/jurnal/index.php/epigrap he.
}

ada tiga pendekatan yang dianjurkan oleh Sechreiter, yaitu matrealistik, fungsionalistik dan semiotik. Matrealistik berkaitan dengan isu eknomi maupun ekologi; sedangkan fungsionalistik, bertautan dengan interaksi dalam jejaring sosial; dan terakhir semiotik, mempunyai kaitan erat dengan simbol-simbol yang ada di dalam suatu masyarakat. ${ }^{17}$ Dari upaya tersebut diharapkan akan mendapat teks-teks budaya (cultural text) yang menjadi elemen bagi refleksi pembangunan teologi lokal-kontekstual.

Tahap berikutnya adalah upaya membuka tradisi gereja (opening the tradition). Pada fase ini tradisi gereja dianalisis dan dibedah. ${ }^{18}$ Proses ini dilakukan untuk melihat rentetan peristiwa gereja, yang secara holistik, belum langsung menjumpai konteks setempat. Pada tahapan ini yang diperlukan adalah akulturasi, dengan tidak menghilangkan sama sekali bentuk asali kekristenan, tetapi upaya untuk menemukan wajah Yesus yang tersamarkan dalam kon-

\footnotetext{
${ }^{16}$ Fransiskus Borgias, "Membangun Teologi LokalKontekstual Ala Koki Dusun," in Oratio Dies Communitias 47 (Unpar, 2016), 1-34.

${ }^{17}$ Fransiskus Borgias M., "The Quick Growth of the Catholic Church in Manggarai: A Phenomenology of Conversion and Some Explanations," MELINTAS 31, no. 3 (May 19, 2016): 276, accessed October 9, 2020 , http://journal.unpar.ac.id/index.php/melintas/article /view/1919.

${ }^{18}$ Ibid.
} 
teks budaya. Hal ini diperlukan, agar tidak ada pemisahan yang tegas antara gereja dan kebudayaan, karena jika ada jurang antara gereja dan budaya, maka teologi yang dihasilkan tidak kontributif menggumuli konteks.

Berdasarkan pemikiran tersebut, penulis melihat sebenarnya pergulatan maupun perjumpaan dalam konteks multiaspek, termasuk komunitas beragama, akhirnya menghasilkan aspek-aspek seperti folklore, teologi (kerygmatik), konteks, dan juga praksis (doing thelogy). Tanpa disadari aspek-aspek itu telah terinternalisasi, dalam kesadaran beragama dan membentuk corak komunitas keagamaan, dalam hal ini Kristen dan non-Kristen, yang saling melengkapi. Hal tersebut terjadi sebagai akibat dari pembauran dan kualitas perjumpaan yang dibangun berdasarkan keterbukaan terhadap mereka yang berbeda keyakinan.

\section{Konstruksi Folklore Saka Mese Nusa}

Konstruksi saka mese nusa (jaga baik-baik pulau) tidak bisa ditarik keluar oleh sistem kepercayaan asli orang Seram, yakni mitos Nunusaku. ${ }^{19}$ Menurut Bartels, narasi mitos tersebut menggambarkan

19 Dieter Bartels, Di Bawah Naungan Gunung Nunusaku Muslim Kristen Hidup Berdampingan Di Maluku Tengah Jilid II: Sejarah (Jakarta: Kepustakaan Populer Gramedia, 2017), 173. hubungan persaudaraan yang menjadikan nunusaku sebagai pusat bersama munculnya kehidupan orang Seram dan Maluku. Huliselan juga melihat mitos tersebut sebagai konsep sejarah tertua orang Seram yang awalnya berdiam dua suku asli yakni Alune dan Wewale. Konsep Alune dan Wemale merupakan pandangan monodualistis untuk melihat kesempurnaan. ${ }^{20}$ Misalnya orang Alune dan Wemale membagi kosmologi atas dua bagian besar yaitu Langit dan Bumi. Langit disapa sebagai Upu Laonite (Tuan atau Tuhan), dan bumi atau tanah sebagai Ina Ume (perempuan). Klasifikasi langit (laki-laki) dan tanah (perempuan) menjadi dasar terhadap berbagai hal yang berkaitan dengan kehidupan keagamaan atau religi mereka. Gunung (laki-laki), pantai (perempuan), dengan demikian dualistis oposisi ini memberikan pengertian bahwa perpaduan kedua unsur tersebut adalah suatu kesempurnaan.

Sebab itu reproduksi kultural orang Seram Bagian Barat, mengenai saka mese nusa juga berangkat dari dasar tersebut. Secara kultural narasi tersebut mengandung makna agar kehidupan tidak boleh ceraiberai, tetapi orang Seram Bagian Barat mempunyai struktur budaya yang

\footnotetext{
${ }^{20}$ Tontji Soumokil, Reintegrasi Sosial Pasca Konflik Di Maluku (Salatiga: Satya Wacana Press, 2011), 48.
} 
merupakan basis pemberi arah (kritiskonstruktif) dan reposisi bagi kekuatankekuatan politik, atau kekuasaan, maupun berbagai agama-agama dalam rangka rekonstruksi tatanan masyarakat multireligi.

Pandangan ini kemudian dilegitimasikan pada pemekaran Kabupaten Seram Bagian Barat, dari Kabupaten Maluku Tengah, pada tanggal 7 Januari tahun 2003, dan folklore saka mese nusa dijadikan sebagai moto Kabupaten Seram Bagian Barat. Hal ini merupakan nilai-nilai kultural yang sudah dapat dilembagakan dalam aktifitas politik pemerintahan, sehingga memberikan jaminan yang kuat pada keberlanjutan harmoni, dan perdamaian orang Seram Bagian Barat yang multireligi.

Folklore saka mese nusa mengandung pengertian yang sangat dalam. Narasi ini sudah lama sejak zaman datuk-datuk. Hal tersebut dilihat sebagai suatu warisan nilai, dalam pengertian himbauan kepada siapa saja yang berada dalam wilayah Seram Bagian Barat, sebagai suatu kesatuan teritorial pada pulau Seram (Nusa Ina), untuk menjaga dan mempertahankan pulau sekuat-kuatnya dengan bertumpu pada

\footnotetext{
${ }^{21}$ Hasil wawancara dengan mantan ketua koordinator raja-raja negeri Seram Bagian Barat (ketua Latupatti), Elly Kwalomine (69 Tahun), Piru, 1 juli 2018, pukul 16.00 WITA.
}

kekuatan adat istiadat. ${ }^{21}$ Dengan demikian menurut Bapa Cho, saka mese nusa merupakan sumpahan dari datuk-datuk, dan jika melanggar sumpahan tersebut maka ada konsekuensi. Dalam dialek lokal dikenal dengan sei hale hatu-hatu lisa pei, sei lesi sou-soulesi ei artinya sapa balik batu, batu gepe dia, sapa langgar sumpah, sumpah bunuh dia, ${ }^{22}$ (baca: siapa balik batu, batu akan kembali tindih dia, siapa yang melanggar sumpah, sumpah akan membunuh dia). Pengertiannya tidak boleh langgar sumpahan tersebut, dengan demikian jika sudah miliki tanah ini, maka harus jaga. Karena tanah ini milik bersama (somawakubau) yang bisa dijadikan sebagai tempat tumpuan eksistensi, kehidupan orang Seram Bagian Barat.

Sebab itu, dalam kelangsungan hidup suatu masyarakat Seram Bagian Barat, pemeliharaan terhadap nilai-nilai adat kebiasaan, yang tertanam dalam ikatanikatan kultural sangatlah penting. Ikatanikatan kultural muncul spontan, sebagai nilai informal (informal values), yaitu nilai yang dianut bersama, yang memungkinkan orang untuk bekerja bersama dalam sebuah masyarakat. Nilai-nilai spontan yang muncul mempunyai asal-asal usul, yakni lahir

\footnotetext{
${ }^{22}$ Hasil Wawancara dengan Chau.Pirsouw (54 Tahun) Piru, tanggal 2 juli 2018 pukul 20.00 WIT.
} 
dari interaksi mendalam, bahkan sampai negosiasi-negosiasi yang terstruktur. ${ }^{23}$ Jika berdasarkan sudut pandang ini, maka folklore saka mese nusa dapat dikatakan sebagai restorasi kondisi masyarakat yang multi-religi.

\section{Folklore Saka Mese Nusa sebagai Sumber Teologi Lokal}

Folklore saka mese nusa merupakan pengakuan pengetahuan kolektif yang masih dipelihara hingga saat ini. Dalam kerangka itu penulis menelusuri pandangan dunia tentang foklore saka mese nusa di Piru. Dari penelitian, penulis mendapati bahwa sungai, tanah, gunung, hutan di dalam keyakinan tradisional bukan dilihat sebagai hasil buatan manusia, tetapi dari kekuatan yang tertinggi. ${ }^{24}$ Sejak kecil masyarakat Seram Bagian Barat sudah terbiasa mendengar kapata maupun pasawari (baca: nyanyian dan doa adat). Narasi ini juga dapat dilihat dari yang dibilang oleh Tiwery. Dalam penelitiannya di Maluku Tengah, Tiwery mengemukakan bahwa narasi akan kekuatan tertinggi terlihat dalam dialek lokal yaitu: ina pohum ama latuhala, artinya ada penguasa yang

${ }^{23}$ Francis Fukuyama, "Social Capital," in Culture Matters: How Values Shape Human Progress, ed. Lawrence Harrison and Samuel Huntington (New York: Basic Books, 2000), 98-111.

24 Hasil wawancara dengan Yan.Akerina (48 Tahun), Piru tanggal 3 Juli, 2018, pukul 17.00 WIT menciptakan pulau ini. $^{25}$ Manusia atau leluhur pertama yang ada di pulau ini tinggal di gunung yang keramat. Gunung yang dimaksud yaitu Nunusaku. Gunung tersebut tidak bisa dilihat oleh mata manusia biasa. Nunusaku juga diyakini sebagai pusat bersama munculnya semua orang Maluku.

Bapak Dani Titawano mengatakan bahwa orang Seram Bagian Barat percaya bahwa Nunusaku adalah asal muasal leluhur mereka. ${ }^{26}$ Di tempat itu, leluhur melahirkan tata aturan hidup bersama. Bagi orang yang tinggal di pulau Seram tidak akan susah karena Upu Laonite (Tuhan) telah menyediakan alam yang sangat kaya. Tanah yang subur, menyediakan berbagai kebutuhan, bagi semua anak cucu. Siapa saja yang datang ke bumi Seram Bagian Barat tidak mengalami kesusahan karena alam telah menyediakan banyak hal untuk kehidupan. $^{27}$

Informasi lain juga menjelaskan bahwa folklore saka mese nusa digambarkan sebagai perangkat sinyal dan memori kultural, yang bukan hanya menggambarkan asal muasal leluhur orang

\footnotetext{
${ }^{25}$ Weldemina Yudith Tiwery, Teologi Ina Terlahir Dari Rahim Maluku (Jakarta: BPK Gunung Mulia, 2015), 182.

${ }^{26}$ Hasil wawncara dengan Riyanto Manupasa (40 Tahun), Piru tanggal 4 Juli 2018, pukul 10.00 WIT

${ }^{27}$ Hasil wawancara dengan Marthen Tetehuka (58 Tahun), Piru tanggal 4 Juli 2018, pukul 19.00 WIT
} 
Maluku, tetapi dimaknai juga sebagai simbol penyatuan dan perlindungan dari yang Ilahi dan dimanifestasikan oleh leluhur melalui hikmat lokal yang diterima dari langit. $^{28}$

Narasi dari para informan, yang menjelaskan tentang asal-muasal kehidupan, dengan pusatnya di Nunusaku, menjadikan folklore saka mese nusa sebagai kesadaran sejarah, dan tema sentralnya adalah tindakan-tindakan yang mulia dari para leluhur. Para pendahulu juga mewarisi landasan bagi negeri, beserta dengan semua tradisi bagi generasi selanjutnya. Warisan folklore saka mese nusa, yang merupakan akronim dari dua suku pertama yaitu Alune dan Wemale, sekaligus memperlihatkan suasana rekonsiliasi yang paling tinggi dari kedua kelompok para leluhur. Para leluhur Alune dan Wemale menciptakan folklor yang mengandung spirit persatuan. Karena realitas perbedaan memang sudah ada di dalam masyarakat, tetapi tidak memisahkan atau membedakan, malah sebaliknya menegaskan persatuan. ${ }^{29}$

Spirit persatuan ini mengalami tantangan ketika berjumpa dengan Kristen dan Islam. Tidak bisa dipungkiri masyarakat yang memegang adat dan tradisi, kehi-

28 Hasil wawancara dengan Agus Salenusa (42 Tahun) Piru tanggal 4 Juli 2018, Pukul 11.00 WIT.

${ }^{29}$ Tiwery, Teologi Ina Terlahir Dari Rahim Maluku. dupannya langsung dipengaruhi oleh kehadiran agama-agama yang datang dari Eropa maupun Timur Tengah. Misalnya ddalam kekristenan, riset dari Tubaka memperlihatkan bahwa Agama Kristen, dalam hal ini Protestan, hadir sekaligus menjadi warisan bagi masyarakat di Maluku. Kehadiranya tidak serta merta diterima dengan sadar oleh leluhur orang Maluku, sebaliknya peyebarannya mengalami tantangan bagi adat dan budaya lokal. ${ }^{30}$ Cooley secara jelas memperlihatkan adanya dikatomi antara agama Kristen sebagai hasil pekabaran Injil dari Barat dengan kehidupan pranata adat di kalangan masyarakat tradisonal. ${ }^{31}$

Dikatominya menjelaskan bahwa agama Kristen Protestan menempatkan adat lebih rendah dari ajaran agama. Hal ini dikarenakan semua praktek kebudayaan atau adat, yang di luar dari teks kitab suci, dilihat sebagai berhala. Senada dengan hal tersebut Tiwery juga menjelaskan bahwa agama dengan perspektif budaya daerah asalnya (Kristen yang dipengaruhi oleh budaya barat dan Islam yang dipengaruhi oleh budaya Arab) memaksa masyarakat tradisonal yang hendak menjadi penganutnya untuk menanggalkan pola-pola tra-

\footnotetext{
${ }^{30}$ Manaf Tubaka, "Menemukan Identitas Bersama: Dialetika Protestanisme Dan Islam Di Maluku," Sulesana 12, no. 2 (2018): 169-180.

${ }^{31}$ Tiwery, Teologi Ina Terlahir Dari Rahim Maluku.
} 
disionalnya baik berupa pola atribut fisik, pola pikir, maupun pola relasi sosial yang berlaku dalam prananata budaya masyarakat tradisional. ${ }^{32}$ Sebagai contoh ketika seorang hendak menjadi pemeluk agama, orang tersebut harus meninggalkan nama lamanya, yang dianggap kafir, dan mengenakan nama baru yang identik dengan agama tersebut. ${ }^{33}$ Orang Maluku dan Seram Bagian Barat dianggap beragama jika menggunakan nama agamanya. Perubahan tersebut tidak hanya menyangkut nama tetapi juga pola perilaku, atribut, dan gaya hidup orang tersebut akan mengalami perubahan sesuai dengan tuntutan agamanya.

Realitas kehidupan masyarakat Seram Bagian Barat telah memperlihatkan terjadinya pelemahan terhadap budaya lokal. Padahal, nilai keutamaan bukan saja di dapat dalam agama-agama, tetapi juga di dalam kearifan lokal (local genius), yang memiliki nilai-nilai keutamaan diantaranya persaudaraan, kesetaraan, dan kebaikan. ${ }^{34}$ Penemuan dan panggilan nilai tersebut berkonstribusi bagi praksis kehidupan keagamaan, khususnya dalam konteks yang multualistik. ${ }^{35}$

\footnotetext{
${ }^{32}$ Tiwery, Teologi Ina, 184-185.

33 Hasil wawancara dengan Dani Titawano (55 Tahun), Piru, tanggal 2 juli 2018 pukul 20.00 WIT.

34 John Christian Ruhulessin, "Paradigma Etika Publik Dalam Kearifan Lokal Pela," Jurnal Filsafat 29, no. 2 (2019): 183-205.
}

Kenyataan lain juga memperlihatkan bahwa agama memberi pengaruh terhadap kebudayaan kelompok masyarakat. ${ }^{36}$ Nilai-nilai adat dan aturannya dinilai berlawanan dengan doktrin agama dan harus ditinggalkan. Pada akhirnya, terjadi intervensi dari pihak agama untuk melakukan pemisahan dan pengelompokan secara tibatiba dari luar. Peristiwa tersebut membantu memperlihatkan bahwa sesuatu yang baru ketika dipaksakan masuk menjadi sebuah identitas pada akhirnya menciptakan tembok diantara masyarakat. Disinilah letak perbedaan pola agama, dan folklore saka mese nusa. Folklore memiliki sejarah yang kuat dalam masyarakat, dan mempunyai urgenitas untuk menyatukan serta dapat dipakai sebagai sumber membangun teologi lokal yang khas.

Di sisi yang lain, orang Seram Bagian Barat juga mengalami perjumpaan dengan komunitas non-Kristen. Komunitas non-Kristen yang dimaksudkan adalah orang Button yang beragama Islam. Menurut tradisi oral, orang Buton keluar dari Sulawesi Tenggara sudah dengan identitas agama Islam. Hal ini disebabkan karena mereka dipimpin oleh Raja yang sudah

\footnotetext{
${ }^{35}$ Ibid.

36 Laode M. Bauto, "Perpektif Agama Dan Kebudayaan Dalam Kehidupan Masyarakat Indonesia," Jurnal Pendidikan Ilmu Sosial 23, no. 2 (2014): 11-25.
} 
masuk Islam pada abad ke-16. Pada abad ke-16 orang Buton bermigrasi ke pulau Ambon dan melanjutkan perjalanan ke pulau Seram Bagian Barat, kemudian menetap di negeri Piru. Orang Buton diberi izin untuk tinggal di salah satu dusun, yakni dusun Waimeteng Pantai. Mereka mengakui tidak pernah dintervensi atau dipaksa untuk mengikuti agama dari masyarakat setempat, malah sebaliknya melalui hubungan interaksi sosial sehari-hari pada akhirnya terbangun ikatan di antara pendatang dan penduduk asli. ${ }^{37}$ Inilah yang menurut Putnam, hubungan keseharian sebagai cara membangun hubungan saling percaya (social trust) dalam masyarakat. ${ }^{38}$

Perjumpaan sehari-hari tersebut pada akhirnya menjadi kekuatan hubungan masyarakat yang multualistik, karena melalui itu kelompok yang satu dapat mendengarkan kelompok yang lain juga secara lebih otentik. Melalui mendengarkan dan belajar dari kelompok lain mereka secara terbuka menjelaskan bahwa suku dan agama memang berbeda, tetapi orang Piru sudah menganggap mereka seperti saudara, dan karena sudah menjadi saudara, maka wajib saling tolong menolong di antara

\footnotetext{
37 Hasil wawancara denngan Abdila.Tomia (59 Tahun), 4 Juli 2018, pukul 18.00 WIT

${ }^{38}$ Robert D. Putnam, "Tuning in, Tuning out: The Strange Disappearance of Social Capital in America," PS: Political Science \&amp; Politics 28,
}

saudara. Hal tersebut kemudian teraktualisasikan dalam perayaan-perayaan harihari keagamaan, yang mana orang Buton selalu membawa makanan khas Lebaran ke orang Piru, dan pada perayaan hari Natal orang Buton turut berpartisipasi dalam acara-acara drama. Sebaliknya, pada perayaan Halal bil Halal, orang Piru juga melakukan hal yang sama yakni berpartispasi dalam perayaan-perayaan hari keagamaan tersebut.

Relasi dan ikatan sosial ini mulai diterpa ujian ketika terjadi konflik 19992004, yaitu dualistik-konfrontatif antara orang Maluku yang bergama Kristen dan Islam. Mereka saling serang dan menghancurkan karena fanatisme agama. Kenyataan tersebut dapat ditemukan di berbagai tempat di Maluku, tetapi di Piru sendiri masyarakatnya justru tetap hidup damai dan saling melindungi. Hal tersebut dibuktikan salah satunya dengan tetap utuhnya sebuah masjid di Waimeteng Pantai, yang sama sekali tidak dibakar atau dirusak karena masjid itu juga dikerjakan bukan hanya oleh orang Buton, tetapi juga dari orang Piru yang beragama Kristen. Karakter hubungan agama yang inklusif

no. 4 (December 1, 1995): 664-684, accessed October 9, 2020, https://go.gale.com/ps/i.do? $\mathrm{p}=\mathrm{AONE} \& \mathrm{sw}=\mathrm{w} \& \mathrm{issn}=10490965 \& \mathrm{v}=2.1 \& \mathrm{it}=\mathrm{r} \& \mathrm{id}$ $=$ GALE\%7CA17839301\&sid=googleScholar\&link access $=$ fulltext. 
dan melintasi batas, seperti yang telah penulis paparkan di atas, berangkat dari interpertasi mereka terhadap collective memory masyarakat Seram Bagian Barat, yang bersumber dari mitos nunusaku dan folklore saka mese nusa.

\section{Folklore Saka Mese Nusa sebagai Teologi}

\section{Lokal Orang Seram Bagian Barat}

Dinamika perjumpaan komunitas beragama, dan juga aspek budaya tradisional (folklore), dengan sendirinya membentuk pandangan eksistensi manusia, mengenai apa yang diyakininya (imanen), dalam suatu konteks lokal. Secara sederhana berbicara mengenai iman, maka itu sudah berbicara mengenai konsep teologi. Pandangan mengenai teologi sendiripun, ada beragam macam. Misalnya Paul Knitter, yang dikutip oleh Eben Nuban Timo, menjelaskan bahwa teologi merupakan percakapan tentang Tuhan. Berasal dari pengalaman dan pergumulan manusia yang selalu berwarna dan tidak bisa disangkali. Itu sebabnya teologi berakar dalam biografi. ${ }^{39}$ Adapun juga menurut Choan Seng Song, teologi itu selalu terikat pada konteks di mana kita berasal, di mana kita berada, dan ke mana kita berharap akan pergi. Teologi karena itu, terikat oleh

\footnotetext{
39 Timo, Polifonik Bukan Monofonik, 208.
}

${ }^{40}$ Song, Sebutkanlah Nama-Nama Kami, 87. gravitasi. $^{40}$ Dengan demikian, menurut Eben Nuban Timo, teologi itu percakapan manusia tentang Allah yang dikondisikan oleh ruang dan waktu di mana manusia itu hidup, dan juga oleh pengalaman-pengalaman yang manusia jalani termasuk di dalamnya ada aspek psikologi, budaya, dan tradisi. ${ }^{41}$ Teologi mengasumsikan adanya dialog yang dinamis dan dialektis antara pernyataan Allah dan pengalaman manusia.

Dari gambaran definisi teologi tersebut, memberikan pengertian bahwa teologi bukanlah sesuatu yang mengambang, yang kosong tanpa makna, tetapi teologi itu berhubungan dengan tempat atau lokasi, tindakan, perasaan, bahkan juga makna bagi setiap kehidupan manusia, karena itu, hakikat teologi selalu berada dan hidup dalam dunia personal maupun komunal, yang selalu bergerak seiring dengan kreasi-kreasi kemanusiaan atas dunianya (kosmos). Dengan demikian, menurut penulis epistemologi teologi lokal yang sesuai dengan konteks orang Seram Bagian Barat adalah teologi negosisasi inklusif. Pertimbangannya, teologi pada konteks hari ini bukan hanya berpusat pada percakapan tentang gambaran Allah yang ada di teks kitab suci (definisi kalsik-tradisional), karena jika mempertahankan definisi klasik-

\footnotetext{
${ }^{41}$ Timo, Polifonik Bukan Monofonik, 210.
} 
tradisional, maka akan menciptakan arogansi di kalangan agama yang akan menjadikan teologi sebagai kajian eksklusif. Teologi bagi penulis bukan eksklusif, melainkan negosiasi-inklusif. Jika teologi sebagai kajian negosiasi-inklusif, maka definisi teologi yang lebih sesuai menurut penulis, bukan hanya percakapan tentang Allah saja, tetapi sebagai suatu refleksi iman, akan gambaran wajah Allah di antara orang-orang beriman. Proses refleksi bukan terjadi di ruang hampa, melainkan terjadi di dalam ruang bersama, yang ada berbagai macam orang dengan gagasan tentang Allah.

Pertemuan berbagai macam orang dengan ide-ide tentang Allah dalam ruang bersama inilah yang menyebabkan adanya suatu negosiasi terhadap pemahaman teologi, yang akhirnya membuat teologi itu inklusif. Kenapa demikian? Karena ide tentang Allah yang ada di dalam suatu kelompok tidak terjadi begitu saja, tetapi dipengaruhi oleh tempat yang di tempati. Jika tempat yang ditempati itu multi-aspek, termasuk agama, maka teologi yang dihayati adalah teologi yang inklusif, karena tidak menutup kemungkinan bahwa ada interaksi dari orang yang berbeda

42 Yohanes Krismantyo Susanta, "Orang Kristen Dan Politik: Belajar Dari Kasus Salomo Dan Adonia Dalam Persaingan Menuju Takhta," DUNAMIS: Jurnal Teologi dan Pendidikan Kristiani 4, no. 1 secara agama yang akhirnya menciptakan teologi inklusif. Sebab itu, teologi itu tidak hanya berhubungan dengan refleksi, yang hanya mencakup pikiran saja, tetapi harus nyata juga dalam perjuangan kasih kepada semua umat. ${ }^{42}$ Karena bisa dilakukan oleh umat dan bersama umat, maka semua orang bisa berteologi dalam rangka untuk membangun teologi sesuai dengan sudut pandang yang dianut.

Pertanyaan yang kemudian bisa diajukan adalah apakah teologi yang sementara dijalani merupakan teologi yang sesuai dengan sudut pandang yang dianut oleh orang Seram Bagian Barat? Untuk menjawab pertanyaan semacam itu, maka perlu melihat sejarah masuknya Kekristenan dan Komunitas beragama lain yang penulis telah paparkan pada bagian sebelumnya. Secara singkat, Kekristenan ditandai dengan datangnya para misionaris dari Eropa ke Maluku, terlebih khusus ke pulau Seram Bagian Barat. Kedatangan misionaris ini bersamaan dengan datangnya kolonialisme dalam melakukan ekspansi dengan tujuan untuk menguasai rempah-rempah di Seram-Maluku. Selain tujuan ekonomi dan politik, Injil pun disebarkan oleh para misionaris. Ketika para misionaris mewar-

(October 25, 2019): 22-36, accessed October 9, 2020, https://fokus.tempo.co/read/1149698/sebabcekcok- 
takan Injil, secara tidak langsung Injil yang disebarkan adalah Injil yang telah dibungkus oleh kebudayaan mereka, lalu mereka mewartakannya lebih lanjut kepada orang dalam sebuah konteks kultur yang berbeda.

Dengan demikian, hal yang bisa dilihat adalah pertama, ada misionaris yang mewartakan Injil; kedua, orang Seram Bagian Barat; dan ketiga, kebudayaan. Ketiga aspek ini saling terlibat dan berinteraksi. Sederhananya, ketika misionaris melakukan tugas dan kewajiban mereka, sesungguhnya mereka sudah melakukan dua tahap, yaitu dekontekstualisasi dan rekontekstualisasi. Phan mengatakan bahwa hal tersebut merupakan inkulturasi. Inkulturasi yang dimaksudkan Phan adalah sebuah drama perjumpaan antara setidaknya tiga kebudayaan. Diantaranya kebudayaan di mana Injil itu muncul (teks kitab suci), tradisi Kristiani orang Eropa, dan kepada orang yang diwartakan Injil tersebut. $^{43}$

Pada pihak lain, dengan hadirnya komunitas beragama lain secara tidak langsung kehidupan orang Seram Bagian Barat berubah dari cara hidup tradisional

\footnotetext{
${ }^{43}$ Peter C. Phan, In Our Own Tongues, Perspective from Asia on Mission and Inculturation (New York: Orbis Books, 2003), 426.

${ }^{44}$ Rita Smith Kipp, "Conversion by Affiliation: The History of the Karo Batak Protestant Church,"
}

menuju ke suatu pandangan dunia yang asing. Perubahan ini akhirnya membuat kehidupan mereka ditata dengan cara hidup baru, yang didadasarkan pada iman Kristiani dan kehadiran komunitas beragama lain. Dengan demikian, mereka ada dalam dua pandangan. Pertama, pandangan keagamaan, kedua warisan folklore. Tetapi, di dalam lingkungan dan identitas serta pemahaman iman baru yang terus berkembang, komunitas keagamaan menafsirkan ulang kehidupan dan pengalaman mereka. ${ }^{44}$ Proses hermeneutika sosialrelijius ini membangkitkan komitmenkomitmen terhadap warisan tradisi terdahulu, hal ini kemudian menunjukan bahwa orang Seram Bagian Barat, tidak bisa melepaskan kebudayaan mereka sendiri. Itu berarti bahwa mereka tidak bisa hidup tanpa pegangan atau kebudayaan. Sebab itu, dibutuhkanlah suatu rancangan teologi lokal yang khas bagi mereka.

Dengan mengikuti langkah-langkah teologi lokal, maka aktivitas yang harus diperhatikan yaitu membuka budaya (opening the culture), dan membuka tradisi keagamaan (opening the tradition). ${ }^{45} \mathrm{Hal}$ yang harus disadari dalam tradisi kitab suci,

American Ethnologist 22, no. 4 (November 1, 1995): 868-882, accessed October 9, 2020, http:// doi.wiley.com/10.1525/ae.1995.22.4.02a00110.

${ }^{45}$ Schreiter, Rancang Bangun Teologi Lokal, 132. 
semua teologi adalah teologi yang lokalkontekstual, yang digunakan untuk menjawab dan menanggapi tantangan lokalkontekstual. Kalau kesadaran demikian sudah ada, maka selanjutnya orang secara kritis mengkaji dan menganalisis konteks lokalnya sendiri. Dalam menganalisis konteks lokal, akan berhadapan dengan kesadaran bahwa budaya sebagai kebutuhan yang nyata, aktual, dan mendesak. Pola membuka kultur, kemudian yang menentukan bagaimana segala sesuatu dilakukan dan dikerjakan dalam sebuah kultur.

Berdasarkan langkah tersebut jika penulis memakai folklore saka mese nusa sebagai inti atau poros utama teologi lokal orang Seram Bagian Barat, maka refleksi teologi lokal yang dihasilkan adalah teologi lokal yang tidak membedakan orang karena agama atau suku, tetapi dari teks budaya tersebut melahirkan teologi yang berbasis pada solidaritas dan perdamaian dengan orang berbeda agama.

Tahapan berikutnya, dengan melihat perjumpaan kolonialisme global dengan orang Asia, akhirnya ada transformasi besar. Dalam pengertian kolonialisme menggoncang struktur masyarakat tradi-

46 Mariani Harmadi, “Metafora 'Meja Makan' Sebagai Upaya Membangun Toleransi Di Tengah Kehidupan Masyarakat Indonesia Yang Majemuk," DUNAMIS: Jurnal Teologi dan Pendidikan Kristiani 4, no. 1 (October 25, 2019): 99-110, sional dengan program modern dan globalisasi. Hal ini dapat membuat seseorang atau kelompok mengalami pelemahan atau kehilangan identitasnya. ${ }^{46}$ Perjumpaan tersebut juga menyebabkan mereka tidak lagi satu entitas. Kendati mereka sudah ada di dalam kepelbagaian entitas, justru mereka tidak hilang, dalam pengertian warisan tradisi dan kebudayaan, masih tetap bertahan dalam pelbagai bentuk dan negosiasi. $^{47}$ Perubahan semacam demikian, akhirnya berimplikasi juga pada munculnya keagamaan yang beragam, yakni Kristen dan Non-Kristen

Melihat kenyataan tersebut, langkah konkrit yang mesti dilakukan adalah membuka tradisi keagamaan, dengan cara menganilisis atau membedah tradisi keagamaan itu sendiri. Model ini dilakukan tergantung dengan situasi dan konteks tertentu. Misalnya dalam konteks Kekristenan, perlu dilakukan upaya adaptasi kultural agar teologi yang dihasilkan adalah teologi yang muncul dari dalam. Konkritnya jika berteologi dengan memakai folklore saka mese nusa, maka warisan kultural ketika berjumpa dengan tradisi keagamaan akan menghasilkan suatu

accessed October 9, 2020, http://www.sttintheos. ac.id/e-journal/index.php/dunamis.

${ }^{47}$ Borgias M., "The Quick Growth of the Catholic Church in Manggarai: A Phenomenology of Conversion and Some Explanations." 
afirmasi dalam suatu komunitas setempat. Dalam pengertian warisan kultural ini bisa saling memperkaya tradisi keagamaan untuk menghasilkan makna-makna teologi lokal yang lintas komunitas beragama.

Berdasarkan hasil penelitian dari penulis, perjumpaan dengan komunitas non-Kristen menghasilkan suatu kesadaran kolektif baru yang membentuk frame cara berpikir baru. Kesadaran kolektif baru yang dimaksudkan yaitu, orang Buton diangggap sebagai anak piara (anak angkat) dari orang Piru. Secara hurufiah kata anak piara mengandung makna sekalipun tidak memiliki hubungan genelogis (darah), tetapi orang pendatang yang berbeda, baik secara suku dan agama, sudah dianggap sebagai saudara angkat dari masyarakat Seram Bagian Barat. Hal tersebut menjelaskan bahwa folklore saka mese nusa bukan hanya sebagai reproduksi kultural orang Seram Bagian Barat, tetapi juga menarik garis batas baru dalam rangka menciptakan transformasi moralitas yang lebih luas. Transformasi yang dimaksudkan, yaitu moral yang sebelumnya hanya untuk orang Kristen, menjadi moral yang menjangkau komunitas yang non-Kristen. Hal ini kemudian dilihat sebagai teologi yang tetap

\footnotetext{
48 Timo, Polifonik Bukan Monofonik, 357.

49 Vincent Kalvin Wenno, “'Inisiatif Untuk Mengasihi' Membaca Etika Paulus Dalam Roma 12:9-21 Serta Implikasinya Bagi Pembangunan
}

membangun relasi dengan Tuhan, tetapi solider dengan sesama manusia yang berbeda secara agama.

Sebab itu, jika mau mengerjakan teologi yang berbasis pada konteks, maka folklore saka mese nusa harus dihargai dan dijadikan sebagai bahan baku teologi lokal. Folklore saka mese nusa tidak boleh sekedar dianggap sebaga obyek, melainkan khazanah budaya tersebut, beserta maknamakna yang terkandung di dalamnya, perlu ditempatkan di samping teks Kitab Suci, bahkan menurut Eben Nuban Timo harus dilihat sebagai kelanjutan Injil. $^{48}$ Jika dilihat sebagai kelanjutan Injil, maka folklore saka mese nusa sudah ada preseden di dalam teks Kitab Suci maupun tradisi Gereja. Contoh dalam Roma 12:9-21 memperlihatkan cara dan strategi komunitas Krisiten dalam berteologi di tengah keberagaman. Roma 12:9-21 memperlihatkan komunitas Kristen hidup di tengah keberagamaan dunia yang mempunyai potensi timbulnya konflik. Kemajemukan tersebut membantu komunitas Kristen pada saat itu untuk ada dalam peralihan etika menuju ke komunitas non kekristenan. ${ }^{49}$

Hal ini berarti bahwa perhatian pada Injil di dalam Alkitab harus dibarengi

Perdamaian," KENOSIS: Jurnal Kajian Teologi 3, no. 2 (December 1, 2017): 114-128, accessed October 9, 2020, http://e-journal.iaknambon .ac.id/index.php/KNS/article/view/8. 
dengan kepekaan mengendus Injil di dalam kearifan lokal masyarakat. Karena apa yang disampaikan oleh Paulus, hal tersebut juga ada dalam tradisi suci kelompok etnis bahkan cultural state orang Seram Bagian Barat. Ini yang kemudian dilihat sebagai sosok hikayat Kristus yang hadir secara tersamarkan dalam mitos, legenda dan berbagai kearifan lokal. Bertolak dari hal tersebut, maka Injil tidak hanya dipahami sebagai sesuatu yang datang dari luar, melainkan juga sebagai sesuatu yang sudah ada di dalam budaya atau tata nilai, tata laku, dan tata laksana orang Seram Bagian Barat. Elemen Injil yang merujuk pada karya Allah di dalam Alkitab, seperti yang telah ditunjukan oleh Paulus dalam Roma 9:21, mengandung makna bahwa Injil yang berupa kasih dapat dinyatakan di luar komunitas Kristen. Oleh sebab itu, sambutan manusia kepada nilai-nilai yang ada di dalam folklore saka mese nusa adalah bagian dari inti pemikiran Paulus.

Dengan demikian elemen Injil yang ada di teks Kitab Suci harus dipertautkan dengan folklore yang ada di suatu masyarakat. Karena dengan begitu, maka perwujudan teologi lokal yang dikerjakan dan dihayati oleh masyarakat Seram bagian Barat memiliki cita rasa dan aroma khas, yang sesuai dengan konteksnya, sekaligus teologi yang dihasilkan adalah teologi lokal yang langsung menjumpai semua orang tanpa memandang latar belakang agama.

\section{KESIMPULAN}

Dengan memakai folklore sebagai teologi lokal adalah berarti undangan kepada setiap orang orang untuk melangkah melampaui batas-batasnya. Hal ini disebabkan karena teologi yang dibangun dengan konteks lokal adalah merupakan proses penerimaan terhadap agama lain. Penerimaan ini dilihat sebagai tindakan praksis teologi inkulusif untuk menerima dan hidup bersama. Pada pihak lain, teologi lokal ini juga mengandung penanda untuk menjaga kehidupan yang damai. Pada titik ini, teologi yang dihasilkan bukan hanya teologi yang menggumuli situasi atau konteks saja, tetapi teologi yang dihasilkan adalah teologi yang membawa kepada transformasi yang lebih luas.

\section{DAFTAR PUSTAKA}

Banawiratma, Johanes Baptista Giyana. "Teologi Lokal Dalam Konteks Global." GEMA TEOLOGIKA 1, no. 1 (April 28, 2016): 55. Accessed October 9, 2020. http://journaltheo.ukdw.ac.id/index.php/gemateolo gika/article/view/211.

Bartels, Dieter. Di Bawah Naungan Gunung Nunusaku Muslim Kristen Hidup Berdampingan Di Maluku Tengah Jilid II: Sejarah. Jakarta: Kepustakaan Populer Gramedia, 2017.

Bauto, Laode M. "Perpektif Agama Dan Kebudayaan Dalam Kehidupan 
Masyarakat Indonesia." Jurnal Pendidikan Ilmu Sosial 23, no. 2 (2014): 11-25.

Borgias, Fransiskus. "Membangun Teologi Lokal-Kontekstual Ala Koki Dusun." In Oratio Dies Communitias 47, 1-34. Unpar, 2016.

Borgias M., Fransiskus. "The Quick Growth of the Catholic Church in Manggarai: A Phenomenology of Conversion and Some Explanations." MELINTAS 31, no. 3 (May 19, 2016): 276. Accessed October 9, 2020. http://journal.unpar.ac.id/index.php/m elintas/article/view/1919.

Creswell, John W. Penelitian Kualitatif Dan Design Riset. Yogyakarta: Pustaka Pelajar, 2015.

Dawa, Markus Dominggus L. "Menjadi Jemaat Multikultural: Suatu Visi Untuk Gereja-Gereja Tionghoa Injili Indonesia Yang Hidup Di Tengah Konflik Etnis Dan Diskriminasi Rasial." Veritas: Jurnal Teologi dan Pelayanan 7, no. 1 (2006). Accessed October 9, 2020. http://repository. seabs.ac.id/handle/123456789/132.

Dundes, Alan. The Meaning of Foklore. Edited by Simon J. Brunner. Utah: Utah State University, 2007.

Fukuyama, Francis. "Social Capital." In Culture Matters: How Values Shape Human Progress, edited by Lawrence Harrison and Samuel Huntington. New York: Basic Books, 2000.

Harmadi, Mariani. "Metafora 'Meja Makan' Sebagai Upaya Membangun Toleransi Di Tengah Kehidupan Masyarakat Indonesia Yang Majemuk." DUNAMIS: Jurnal Teologi dan Pendidikan Kristiani 4, no. 1 (October 25, 2019): 99-110. Accessed October 9, 2020. http://www.sttintheos.ac.id/ejournal/index.php/dunamis.
Kipp, Rita Smith. "Conversion by Affiliation: The History of the Karo Batak Protestant Church." American Ethnologist 22, no. 4 (November 1, 1995): 868-882. Accessed October 9, 2020.

http://doi.wiley.com/10.1525/ae.1995. 22.4.02a00110.

Lattu, Izak. "Kekristenan Poliponik: Mendialogkan Teologi Dan Budaya Lokal." Jurnal Teologi Interdisipliner 4 , no. 1 (2009).

"Orality Ritual in Collective Memory: A Theoritical Discussion." Jurnal Pemikiran Sosiologi 6, no. 2 (2019): 94-111.

Phan, Peter C. In Our Own Tongues, Perspective from Asia on Mission and Inculturation. New York: Orbis Books, 2003.

Putnam, Robert D. "Tuning in, Tuning out: The Strange Disappearance of Social Capital in America." PS: Political Science \&amp; Politics 28, no. 4 (December 1, 1995): 664-684. Accessed October 9, 2020. https:// go.gale.com/ps/i.do?p=AONE\&sw $=\mathrm{w}$ \&issn $=10490965 \& v=2.1 \& i t=r \& i d=G$ ALE\%7CA17839301\&sid=googleSc holar\&linkaccess $=$ fulltext.

Raco, J. R. Metode Penelitian Kualitatif, Jenis, Karakteristik, Dan Keunggulan nya. Jakarta: Widya Sari Indonesia, 2010.

Ruhulessin, John Christian. "Paradigma Etika Publik Dalam Kearifan Lokal Pela." Jurnal Filsafat 29, no. 2 (2019): 183-205.

Schreiter, Robert J. Rancang Bangun Teologi Lokal. Edited by Stephen Suleeman. Jakarta: BPK Gunung Mulia, 2001.

Sedmark, Clemens. Doing Local Theology. New York: Orbis Books, 2002. 
Song, Choan-Seng. Sebutkanlah NamaNama Kami. Jakarta: BPK Gunung Mulia, 1989.

Soumokil, Tontji. Reintegrasi Sosial Pasca Konflik Di Maluku. Salatiga: Satya Wacana Press, 2011.

Susanta, Yohanes Krismantyo. "Orang Kristen Dan Politik: Belajar Dari Kasus Salomo Dan Adonia Dalam Persaingan Menuju Takhta." DUNAMIS: Jurnal Teologi dan Pendidikan Kristiani 4, no. 1 (October 25, 2019): 22-36. Accessed October 9, 2020.

Tari, Ezra. "Teologi Tongkonan: Berteologi Dalam Konteks Budaya Toraja." EPIGRAPHE: Jurnal Teologi dan Pelayanan Kristiani 2, no. 2 (January 23, 2019): 93. Accessed October 9, 2020. http://www.stttorsina.ac.id/ jurnal/index.php/epigraphe.
Timo, Eben N. Polifonik Bukan Monofonik. Salatiga: Satya Wacana Press, 2015.

Tiwery, Weldemina Yudith. Teologi Ina Terlahir Dari Rahim Maluku. Jakarta: BPK Gunung Mulia, 2015.

Tubaka, Manaf. "Menemukan Identitas Bersama: Dialetika Protestanisme Dan Islam Di Maluku." Sulesana 12, no. 2 (2018): 169-180.

Wenno, Vincent Kalvin. "'Inisiatif Untuk Mengasihi' Membaca Etika Paulus Dalam Roma 12:9-21 Serta Implikasinya Bagi Pembangunan Perdamaian." KENOSIS: Jurnal Kajian Teologi 3, no. 2 (December 1, 2017): 114-128. Accessed October 9, 2020. http://e-journal.iaknambon.ac.id /index.php/KNS/article/view/8. 